\title{
Determinan Perilaku Seksual Berisiko pada Remaja Makassar (Studi Kasus Santri Darul Arqam Gombara dan SMAN 6)
}

\author{
Determinan of Sexual Behavior Risk in Adolescent Makassar \\ (Case Study on Students of MA Darul Arqam Gombara and SMAN 6)
}

\author{
Masni, St. Fatimah Hamid* \\ Bagian Biostatistik/KKB Fakultas Kesehatan Masyarakat Universitas Hasanuddin \\ (*st.fatimahhamidhealth@gmail.com)
}

\begin{abstract}
ABSTRAK
Masa remaja adalah periode rasa ingin tahu yang besar dan ingin mencoba untuk meniru yang dilihat atau didengar. Rasa ingin tahu membuat remaja lebih permisif untuk melakukan perilaku seksual berisiko, tetapi diduga bahwa pemahaman agama akan menjadi faktor pembeda. Penelitian ini bertujuan mengetahui pengaruh pemahaman agama, peran orangtua, peran teman sebaya dan penggunaan media sosial terhadap perilaku seksual berisiko pada remaja dengan membandingkan antara santri Madrasah Aliyah di Pesantren Darul Arqam Gombara dengan siswa SMAN 6 Makassar. Penelitian observasional dengan rancangan cross sectional study, melibatkan 79 santri MA Darul Arqam Gombara yang dipilih secara keseluruhan dan 274 orang siswa SMAN 6 yang dipilih secara proporsional stratified random sampling. Analisis menggunakan analisis univariat dan bivariat dengan uji chi-square dan uji phi. Hasil penelitian ditemukan ada pengaruh peran orang tua di MA Darul Arqam ( $\mathrm{p}=0,000$, $\varphi=0,403)$ terhadap perilaku seksual berisiko santri sedangkan siswa di SMAN 6 tidak terdapat pengaruh orang tua $(\mathrm{p}=0,472)$ terhadap terhadap perilaku seksual berisiko. Adapun pengaruh pemahaman agama $(\mathrm{p}=0,027, \varphi=0,134)$, teman sebaya $(p=0,000, \varphi=0,339)$ dan penggunaan media sosial $(p=0,035, \varphi=0,128)$ di SMAN 6 terhadap perilaku seksual berisiko pada siswa sedangkan santri di MA Darul Arqam menunjukkan tidak ada pengaruh pemahaman agama $(0,811)$, peran teman sebaya $(0,702)$ dan media sosial $(0,063)$ terhadap perilaku seksual berisiko pada santri. Kata kunci : Perilaku seksual berisiko, remaja, media sosial, Agama
\end{abstract}

\begin{abstract}
Adolescence is a period great curiosity and want to try to imitate what they seen or heard. Curiosity makes teens more permissive to engage in risky sexual behavior, but it is suspected that religious understanding will be a distinguishing factor. This study aims to determine the influence of religious understanding, parent role, peer role and the use of social media against risky sexual behavior in adolescents by comparing the santri Madrasah Aliyah in Darul Arqam Gombara Pesantren with students of SMAN 6 Makassar. Observational research with cross sectional study design, involving 79 students of MA Darul Arqam Gombara selected as sample and 274 students of SMAN 6 selected proportional stratified random sampling. The analysis used univariate and bivariate analysis with chi-square test and phi test. The result of the research shows that there is influence of parent role in MA Darul Arqam $(p=0,000, \varphi=0,403)$ to santri risk sexual behavior whereas student in SMAN 6 there is no influence of parent role $(p=0,472)$ towards sexual risk behavior. The influence of religious understanding $(p=0.027, \varphi=0.134)$, peers $(p=0,000, \varphi=0.339)$ and social media $(p=0.035, \varphi=0.128)$ in SMAN 6 on risky sexual behavior in students whereas in MA Darul Arqam showed no influence of religious understanding $(0,811)$, peer role $(0,702)$ and social media $(0,063)$ toward risky sexual behavior at santri.
\end{abstract}

Keywords : Risk sexual behavior, adolenscent, social media, Religion 


\section{PENDAHULUAN}

Remaja merupakan kelompok rentan terhadap masalah kesehatan reproduksi, pada masa ini terjadi keinginan besar untuk mencoba dan mengetahui hal baru. Masa remaja merupakan periode terjadinya pertumbuhan dan perkembangan yang pesat, baik secara fisik, psikologis maupun intelektual. Sifat khas remaja mempunyai rasa keingintahuan yang besar, menyukai petualangan dan tantangan serta cenderung berani menanggung risiko dan perbuatannya tanpa didahului pertimbangan yang matang. Masa remaja adalah masa transisi dari anak-anak menuju dewasa dan pada masa ini jiwa mereka masih penuh dengan gejolak. Tidak sedikit diantara mereka justru berperilaku menyimpang, bahkan ada yang menjurus ke seks bebas, tindakan kriminal dan penyalahgunaan obat. ${ }^{1}$

Penelitian yang dilakukan oleh Khaerina dalam studi seksualitas dan perilaku seksual di Pesantren Islam Indonesia ditemukan bahwa di tengahtengah komunitas agama yang hidup dengan istilah "seksual tabu", didapatkan bentuk perilaku seksual yang spesifik dan popular di kalangan santri adalah perilaku seksual sesama jenis (baik antara sesama santri laki-laki serta antar sesama santri perempuan), seperti yang dikenal sebagai mairil, dumok, alaq-dalaq, nyempet, muyak lating, lesehan, lesbiola dan lain-lain, tergantung pada lokasi. $^{2}$

Survei Demografi Kesehatan Indonesia tahun 2012 mengenai kesehatan reproduksi remaja menunjukkan persentase remaja pria bisa menerima hubungan seksual sebelum menikah lebih tinggi (7\%) dibandingkan dengan wanita (2\%). Alasan utama remaja pria bisa menerima hubungan seksual pranikah karena menyukai hubungan seksual, saling mencintai dan merencanakan menikah. Remaja pria dengan pendidikan lebih rendah cenderung dapat menerima hubungan seksual sebelum kawin dibandingkan dengan yang berpendidikan lebih tinggi. Aktivitas remaja dalam berpacaran menunjukkan berpegangan tangan adalah hal yang paling banyak mereka lakukan (72\% remaja wanita dan $80 \%$ remaja pria). Remaja pria cenderung lebih banyak melaporkan perilaku berciuman (48\%) dibandingkan dengan remaja wanita (30\%) dan meraba atau merangsang bagian tubuh yang sensitif (sejumlah $30 \%$ remaja pria dan $6 \%$ remaja wanita). ${ }^{3}$
Survei RPJMN Remaja dari tahun 20122014 menggunakan responden remaja berumur 15-24 tahun belum menikah yang dilakukan di Sulawesi Utara menunjukkan bahwa remaja yang hanya melakukan pegangan tangan dari tahun ke tahun persentasenya sangat tinggi atau selalu diatas $90 \%$. Akan tetapi hasil survei ini tidak boleh dilihat dengan satu sudut pandang karena aktivitas ciuman bibir persentasinya pada dua tahun meningkat tajam 39\% pada tahun 2012 kemudian naik menjadi $63 \%$ tahun 2013, meskipun tahun 2014 sedikit melegakan mengalami penurunan menjadi 59\%. Hasil tersebut belum bisa secara sempurna menurun karena aktivitas meraba atau merangsang bagian tubuh tertentu persentasinya meningkat drastis. Aktivitas ini yang teramat membahayakan karena bisa menjurus pada aktivitas layaknya dilakukan suami isteri yang akhirnya bisa hamil diluar pernikahan serta seks bebas. ${ }^{4}$

Menurut penelitian yang dilakukan oleh Paseno menunjukkan bahwa ada hubungan antara media informasi, peran teman sebaya dan peran orang tua dengan perilaku seksual pranikah pada mahasiswa STIK. Sering kali orang tua menolak membicarakan masalah kesehatan reproduksi sehingga mereka kemudian mencari alternatif sumber informasi lain seperti media massa, remaja juga disuguhi film yang berbau seksual dan hp yang dapat mengakses video pornografi. ${ }^{5}$ Perbedaan pemahaman dalam menjalani keyakinan beragama bisa menjadi faktor pembeda, sehingga dicoba mengkaji hal tersebut melalui penelitian. Penelitian ini bertujuan mengetahui pengaruh pemahaman agama atau keyakinan, peran orang tua, peran teman sebaya dan penggunaan media sosial terhadap perilaku seksual berisiko remaja d en ga n membandingkan antara santri Madrasah Aliyah di Pesantren Darul Arqam Gombara Makassar dengan siswa SMA Negeri 6 Makassar.

\section{BAHAN DAN METODE}

Jenis penelitian yang digunakan adalah penelitian observasional analitik dengan rancangan cross sectional study untuk mengetahui pengaruh pemahaman agama atau keyakinan, peran orang tua, peran teman sebaya dan penggunaan media sosial sebagai variabel independen terhadap perilaku seksual berisiko pada remaja sebagai variabel dependen. Penelitian dilakukan di Pondok Pe- 
Tabel 1. Gambaran Karakteristik Responden

\begin{tabular}{|c|c|c|c|c|}
\hline \multirow{3}{*}{ Karakteristik } & \multicolumn{4}{|c|}{ Remaja Siswa Sekolah } \\
\hline & \multicolumn{2}{|c|}{ Pesantren Darul Arqam } & \multicolumn{2}{|c|}{ SMA Negeri 6} \\
\hline & $\mathbf{n}$ & $\%$ & $\mathbf{n}$ & $\%$ \\
\hline \multicolumn{5}{|l|}{ Umur (tahun) } \\
\hline 14 & 3 & 3,8 & 4 & 1,5 \\
\hline 15 & 21 & 26,6 & 74 & 27,0 \\
\hline 16 & 17 & 21,5 & 78 & 28,5 \\
\hline 17 & 22 & 27,8 & 95 & 34,7 \\
\hline 18 & 16 & 20,3 & 23 & 8,4 \\
\hline \multicolumn{5}{|l|}{ Jenis Kelamin } \\
\hline Laki-laki & 52 & 65,8 & 137 & 50 \\
\hline Perempuan & 27 & 34,2 & 137 & 50 \\
\hline \multicolumn{5}{|l|}{ Kelas } \\
\hline $\mathrm{X}$ & 29 & 36,7 & 93 & 33,9 \\
\hline XI & 16 & 20,3 & 91 & 33,2 \\
\hline XII & 34 & 43,0 & 90 & 32,8 \\
\hline \multicolumn{5}{|l|}{ Pemahaman Agama } \\
\hline Kurang & 36 & 45,6 & 132 & 48,2 \\
\hline Cukup & 43 & 54,4 & 142 & 51,8 \\
\hline \multicolumn{5}{|l|}{ Peran Orang Tua } \\
\hline Kurang & 37 & 46,8 & 78 & 28,5 \\
\hline Cukup & 42 & 53,2 & 196 & 71,5 \\
\hline \multicolumn{5}{|l|}{ Peran Teman Sebaya } \\
\hline Tidak Ada & 35 & 44,3 & 125 & 45,6 \\
\hline Ada & 44 & 55,7 & 149 & 54,4 \\
\hline \multicolumn{5}{|l|}{ Penggunaan Media Sosial } \\
\hline Penggunaan Rendah & 47 & 59,5 & 33 & 12,0 \\
\hline Penggunaan Tinggi & 32 & 40,5 & 241 & 88,0 \\
\hline \multicolumn{5}{|l|}{ Perilaku Seksual } \\
\hline Tidak Berisiko & 43 & 54,4 & 104 & 38,0 \\
\hline Berisiko & 36 & 45,6 & 170 & 62,0 \\
\hline
\end{tabular}

Sumber: Data Primer, 2015

santren Darul Arqam Gombara Makassar Provinsi Sulawesi Selatan dan SMA Negeri 6 Makassar. Pengumpulan data penelitian dilakukan pada tanggal 17-21 Februari 2015. Jumlah siswa yang terlibat di Madrasah Aliyah Darul Arqam Gombara sebanyak 79 responden yang dipilih secara keseluruhan (exhaustive sampling) dan di SMA Negeri 6, sebanyak 274 siswa yang dipilih dari populasi dengan metode proporsional stratified random sampling. Pengumpulan data menggunakan data primer. Data dianalisis menggunakan analisis univariat, bivariat dengan uji chi-square selanjutnya disajikan dalam bentuk tabel dan narasi.

\section{HASIL}

Berdasarkan karakteristik responden yang tersaji pada Tabel 1 menunjukkan bahwa umur reponden di pesantren Darul Arqam maupun di SMAN 6, terbanyak berumur 17 tahun yaitu 22 orang $(27,8 \%)$ di Pesantren Darul Arqam dan 95 orang $(34,5 \%)$ di SMAN 6. Berdasarkan jenis kelamin, sebagian besar santri berjenis kelamin laki-laki 52 orang $(65,8 \%)$ dan di SMAN 6, jumlah responden dengan jenis kelamin laki-laki dan perempuan sama banyak yaitu masing-masing 50\% (137 orang). Berdasarkan tingkatan kelas, di pesantren Darul Arqam responden terbanyak pada kelas XII yaitu 34 orang (43\%) sedangkan pada siswa SMAN 6 yang terbanyak adalah kelas X, yaitu 93 orang $(33,9 \%)$.

Pengaruh variabel independen pada Tabel 1 menunjukkan hasil analisis data bahwa di Pesantren Darul Arqam maupun di SMAN 6 lebih 
Tabel 2. Distribusi Responden Berdasarkan Tindakan Seksual Berisiko

\begin{tabular}{|c|c|c|c|c|c|c|c|c|c|c|c|c|}
\hline \multirow{3}{*}{ Tindakan Seksual } & \multicolumn{6}{|c|}{ Pesantren Darul Arqam Gombara } & \multicolumn{6}{|c|}{ SMAN 6 Makassar } \\
\hline & \multicolumn{2}{|c|}{ Sering } & \multicolumn{2}{|c|}{ Jarang } & \multicolumn{2}{|c|}{$\begin{array}{c}\text { Tidak } \\
\text { Pernah }\end{array}$} & \multicolumn{2}{|c|}{ Sering } & \multicolumn{2}{|c|}{ Jarang } & \multicolumn{2}{|c|}{ Tidak Pernah } \\
\hline & $\mathbf{n}$ & $\%$ & $\mathbf{n}$ & $\%$ & $\mathbf{n}$ & $\%$ & $\mathbf{n}$ & $\%$ & $\mathbf{n}$ & $\%$ & $\mathbf{n}$ & $\%$ \\
\hline Berpegangan Tangan & 11 & 13,9 & 38 & 48,1 & 30 & 38,0 & 117 & 42,7 & 113 & 41,2 & 44 & 16,1 \\
\hline Mencium Pipi & 4 & 5,1 & 12 & 15,2 & 63 & 79,7 & 86 & 31,4 & 80 & 29,2 & 108 & 39,4 \\
\hline Berpelukan & 3 & 3,8 & 17 & 21,5 & 59 & 74,7 & 65 & 23,7 & 96 & 35,0 & 113 & 41,2 \\
\hline Mencium Bibir & 1 & 1,3 & 8 & 10,1 & 70 & 88,6 & 56 & 20,4 & 87 & 31,8 & 131 & 47,8 \\
\hline Masturbasi Onani & 1 & 1,3 & 16 & 20,3 & 62 & 78,5 & 12 & 4,4 & 115 & 42,0 & 147 & 53,6 \\
\hline Berfantasi & 1 & 1,3 & 15 & 19,0 & 63 & 79,7 & 9 & 3,3 & 53 & 19,3 & 212 & 77,4 \\
\hline Meraba bagian sensitif & 0 & 0,0 & 6 & 7,6 & 73 & 92,2 & 11 & 4,0 & 56 & 20,4 & 207 & 75,5 \\
\hline Petting & 0 & 0,0 & 3 & 3,8 & 76 & 96,2 & 6 & 2,2 & 40 & 14,6 & 228 & 83,2 \\
\hline Necking & 0 & 0,0 & 4 & 5,1 & 75 & 94,9 & 8 & 2,9 & 52 & 19,0 & 214 & 78,1 \\
\hline Bersenggama & 0 & 0,0 & 1 & 1,3 & 78 & 98,7 & 3 & 1,1 & 11 & 4,0 & 260 & 94,6 \\
\hline
\end{tabular}

Sumber: Data Primer, 2015

Tabel 3. Pengaruh Variabel Independen terhadap Perilaku Seksual Berisiko

\begin{tabular}{|c|c|c|c|c|c|c|c|c|c|c|}
\hline \multirow{4}{*}{ Variabel } & \multicolumn{10}{|c|}{ Perilaku Seksual } \\
\hline & \multicolumn{5}{|c|}{ SMAN 6} & \multicolumn{5}{|c|}{ MA Darul Arqam } \\
\hline & \multicolumn{2}{|c|}{ Berisiko } & \multicolumn{2}{|c|}{$\begin{array}{c}\text { Tidak } \\
\text { Berisiko }\end{array}$} & \multirow{2}{*}{$\begin{array}{c}\text { Uji } \\
\text { Statistik }\end{array}$} & \multicolumn{2}{|c|}{ Berisiko } & \multicolumn{2}{|c|}{$\begin{array}{c}\text { Tidak } \\
\text { Berisiko }\end{array}$} & \multirow{2}{*}{$\begin{array}{c}\text { Uji } \\
\text { Statistik }\end{array}$} \\
\hline & n & $\%$ & $\mathbf{n}$ & $\%$ & & $\mathrm{n}$ & $\%$ & $\mathrm{n}$ & $\%$ & \\
\hline \multicolumn{11}{|c|}{ Pemahaman Agama } \\
\hline Cukup & 45 & 31,7 & 97 & 68,3 & $\mathrm{p}=0,027$ & 30 & 69,8 & 13 & 30,2 & $\mathrm{p}=0,811$ \\
\hline Kurang & 59 & 44,7 & 73 & 55,3 & $\varphi=0,134$ & 26 & 72,2 & 10 & 27,8 & \\
\hline \multicolumn{11}{|l|}{ Peran Orang Tua } \\
\hline Cukup & 77 & 39,3 & 119 & 60,7 & $\mathrm{p}=0,472$ & 24 & 54,5 & 20 & 45,5 & $\mathrm{p}=0,000$ \\
\hline Kurang & 27 & 34,6 & 51 & 65,4 & & 32 & 91,4 & 3 & 8,6 & $\varphi=0,403$ \\
\hline \multicolumn{11}{|c|}{ Peran Teman Sebaya } \\
\hline Ada & 79 & 53,0 & 70 & 47,0 & $\mathrm{p}=0,000$ & 29 & 69,0 & 13 & 31,0 & $\mathrm{p}=0,702$ \\
\hline Tidak ada & 25 & 20,0 & 100 & 80,0 & $\varphi=0,339$ & 27 & 73,0 & 10 & 27,0 & \\
\hline \multicolumn{11}{|l|}{ Media Sosial } \\
\hline Cukup & 7 & 21,2 & 26 & 78,8 & $\mathrm{p}=0,035$ & 37 & 78,7 & 10 & 21,3 & $\mathrm{p}=0,063$ \\
\hline Kurang & 97 & 40,2 & 144 & 59,8 & $\varphi=0,128$ & 19 & 59,4 & 13 & 40,6 & \\
\hline
\end{tabular}

Sumber: Data Primer, 2015

separuh dari responden memiliki pemahaman agama yang cukup, $54,4 \%$ di pesantren Darul Arqam dan 51,8\% di SMAN 6 pada variabel pemahaman agama. Variabel peran orang tua menunjukkan siswa pesantren maupun SMAN 6 lebih banyak yang mempunyai peran orang tua yang cukup 42 orang $(53,2 \%)$ di Pesantren Darul Arqam dan 196 orang $(71,5 \%)$ di SMAN 6 Makassar. Demikian halnya dengan peran teman sebaya, pada dua lokasi penelitian menunjukkan hal yang sama yaitu adanya peran teman sebaya menurut pengakuan responden sebesar 44 orang $(55,7 \%)$ di Pesantren Darul Arqam dan 149 orang (54,4\%) di SMAN 6.
Penggunaan media sosial yang rendah lebih banyak pada Pesantren Darul Arqam (59,5\%) dibandingkan di SMAN 6 dengan penggunaan media sosial yang tinggi $(88,0 \%)$. Untuk perilaku seksual berisiko, kejadiannya lebih banyak di SMAN 6, yaitu 62\% dari 274 responden, sedangkan di Pesantren Darul Arqam hanya 45,6\% dari 79 responden yang pernah melakukan perilaku seksual berisiko (Tabel 1).

Jenis tindakan seksual berisiko yang sering dilakukan, pada responden di pesantren Darul Arqam maupun di SMAN 6 menunjukkan hal yang sama. Di Pesantren, perilaku seksual berisiko 
yang sering dilakukan adalah berpegangan tangan $(13,9 \%)$, mencium pipi atau kening $(5,1 \%)$, berpelukan $(3,8 \%)$, mencium bibir, masturbasi atau Onani dan berfantasi yaitu $1,3 \%$, demikian halnya dengan di SMAN 6 tindakan seksual berisiko yang sering dilakukan adalah berpegangan tangan $(42,7 \%)$, mencium pipi atau kening $(31,4 \%)$, berpelukan $(23,7 \%)$ dan mencium bibir $(20,4 \%)$ dan ada $1,1 \%$ yang mengatakan pernah bersenggama (Tabel 2).

Hasil analisis bivariat yang tersaji pada Tabel 3 menunjukkan bahwa di Pesantren Darul Arqam maupun di SMAN 6 menunjukkan hal yang sama. Di SMAN 6 perilaku seksual berisiko lebih banyak pada responden yang mempunyai pemahaman agama kurang $(44,7 \%)$ sedangkan di Pesantren Darul arqam perilaku seksual berisiko lebih banyak pada responden yang mempunyai pemahaman agama yang kurang $(72,2 \%)$. Hasil uji statistik perilaku seksual berisiko pada siswa SMAN 6 $(p=0,027)$ dengan nilai $\varphi=-0,134$, hal ini berarti bahwa semakin banyak siswa yang mempunyai pemahaman agama yang kurang, maka semakin banyak yang memiliki perilaku seksual berisiko. Sedangkan pada siswa Pesantren Darul Arqam menunjukkan bahwa tidak ada pengaruh pemahaman agama terhadap perilaku seksual berisiko pada santri $(\mathrm{p}=0,811)$.

Variabel peran orang tua, di SMAN 6 perilaku sosial berisiko lebih banyak pada siswa yang peran orang tua cukup $(39,3 \%)$ sedangkan di Pesantren Darul Arqam, perilaku sosial berisiko lebih banyak pada santri yang peran orang tuanya kurang (91,4\%). Hasil analisis statistik menunjukkan bahwa tidak ada pengaruh peran orang tua terhadap perilaku seksual berisiko pada siswa di SMAN $6(\mathrm{p}=0,472)$. Sedangkan di Pesantren Darul Arqam menunjukkan ada pengaruh peran orang tua terhadap perilaku seksual berisiko $(\mathrm{p}<0,05$ dan $\varphi=0,403)$ menunjukkan bahwa ada pengaruh peran orang tua terhadap perilaku seksual berisiko pada santri dengan hubungan keeratan sedang antara peran orang tua terhadap perilaku sosial berisiko.

Pengaruh teman sebaya pada siswa SMAN 6 perilaku sosial berisiko lebih banyak terjadi pada responden yang mengakui ada peran teman sebaya (53,0\%), sedangkan di Pesantren Darul Arqam, perilaku seksual berisiko lebih banyak terjadi pada responden yang mengaku tidak ada peran teman sebaya $(73,0 \%)$. Hasil analisis statistik menunjukkan bahwa ada pengaruh peran teman sebaya terhadap perilaku seksual berisiko $(p=0,000)$ dengan $\varphi=0,339$ menunjukkan tingkat hubungan keeratan sedang antara peran teman sebaya terhadap perilaku sosial berisiko di SMAN 6, sedangkan di Pesantren Darul Arqam menunjukkan bahwa tidak ada pengaruh peran teman sebaya terhadap perilaku seksual berisiko $(p=0,702)$.

Pada variabel penggunaan media sosial pada siswa SMAN 6, perilaku seksual berisiko lebih banyak terjadi pada responden dengan penggunaan media sosial kurang $(40,2 \%)$ sedangkan di Pesantren Darul Arqam, perilaku seksual berisiko lebih banyak terjadi pada responden dengan penggunaan media sosial yang rendah $(78,7 \%)$. Di SMAN 6, hasil analisis statistik menunjukkan bahwa, di SMAN 6 ada pengaruh penggunaan media sosial terhadap perilaku seksual berisiko $(\mathrm{p}<0,05)$ dengan $\varphi=0,128$ menunjukkan tingkat hubungan keeratan lemah antara penggunaan media sosial terhadap perilaku sosial berisiko. Sedangkan hasil analisis statistik di pesantren Darul Arqam, menunjukkan bahwa tidak ada pengaruh penggunaan media sosial terhadap perilaku sosial berisiko $(\mathrm{p}>0,05)$.

\section{PEMBAHASAN}

Kesehatan remaja menjadi perhatian utama dan jika masalah mereka tidak ditangani dengan benar, siklus menjadi lebih kental dan masalahnya menjadi lebih majemuk. Oleh karena itu, menjadi peran individu, baik itu orang tua, guru, profesional kesehatan khususnya perawat untuk memberikan informasi yang benar kepada generasi muda ini dengan cara yang akan memengaruhi kehidupan mereka secara positif. ${ }^{6}$ Perilaku seksual remaja berkaitan dengan sejumlah faktor antara lain peran orang tua, agama, media sosial dan teman sebaya.

Dalam penelitian yang dilakukan oleh Handebo menunjukkan bahwa tingkat kelas, keterhubungan agama, keluarga dan sekolah merupakan prediktor utama perilaku seksual berisiko.? Penanganan masalah perilaku seksual yang kurang tepat akan mengakibatkan dampak negatif pada remaja seperti yang dikemukakan oleh Sarwono, orang tua tabu membicarakan seks dengan remaja dan hubungan orang tua dengan anak terlanjur 
jauh sehingga remaja berpaling ke sumber yang tidak akurat khususnya teman sebaya. ${ }^{8}$

Hasil temuan di lapangan, pada santri Pesantren Darul Arqam menunjukkan ada pengaruh peran orang tua terhadap perilaku seksual berisiko $(\mathrm{p}<0,05)$, tetapi di SMAN 6 tidak ada pengaruh peran orang tua terhadap perilaku seksual berisiko. Bagi santri, meskipun anak tinggal di pesantren atau asrama yang terpisah dengan orang tua, peran orangtua tetap dibutuhkan, baik perhatian maupun dalam hal menyiapkan fasilitas-fasilitas yang dibutuhkan anak. Dibandingkan dengan anak yang tinggal serumah dengan orang tuanya, maka perhatian orang tua bisa saja tidak terlalu terkontrol. Dalam hal pergaulan yang bisa mengarahkan anak untuk melakukan perilaku seksual yang berisiko, dibutuhkan perhatian orang tua yang ekstra ketat. Kehidupan di pesantren menyebabkan anak tidak bisa dikontrol setiap hari oleh orang tua, berbeda dengan anak yang tinggal serumah dengan orang tuanya.

Penelitian ini sejalan dengan penelitian yang dilakukan oleh Gustina, menunjukkan bahwa komunikasi orang tua-remaja merupakan variabel dominan yang berhubungan dengan perilaku seksual berisiko pada remaja. ${ }^{9}$ Temuan lain yang mendukung variabel orang tua sebagai faktor yang memengaruhi perilaku seksual berisiko remaja yaitu Landor, et. al. menunjukkan bahwa religiusitas orang tua berperan sebagai faktor pelindung bagi remaja karena berfungsi sebagai kontrol sosial untuk mengurangi kemungkinan keterlibatan dalam perilaku seksual berisiko. Temuan ini juga menunjukkan bahwa komitmen religius orang tua dikaitkan dengan peningkatan religiusitas remaja, pola asuh otoritatif, dan afiliasi dengan kelompok sebaya yang kurang permisif secara seksual. ${ }^{10}$

Penelitian lain menunjukkan hasil positif yaitu dukungan keluarga dan hubungan positif antara orang tua dan remaja terkait untuk mencegah penyimpangan teman sebaya, jalur utama yang menyebabkan onset dan eskalasi perilaku berisiko tinggi pada masa remaja dan meminimalkan perilaku seksual berisiko dan juga hubungan menghindari atau menurunkan penggunaan alkohol, tembakau, dan obat-obatan yang cenderung melakukan seks. ${ }^{11}$ Dalam ruang lingkup yang berbeda terdapat hasil positif dari penelitian yang dilakukan oleh Wahyu yang menunjukkan bahwa remaja anak jalanan yang melakukan perilaku seksual pranikah mempunyai pengetahuan rendah dan peran orang tua yang kurang baik. ${ }^{12}$

Pemahaman agama dan keyakinan yang baik akan menumbuhkan perilaku yang baik. Remaja memerlukan kemampuan pemecahan masalah yang baik, sehingga remaja mampu menyelesaikan masalah mereka secara efektif. Hasil penelitian menunjukkan pemahaman agama pada siswa SMAN 6, ada pengaruh pemahaman agama terhadap perilaku berisiko sedangkan pada santri MA Darul Arqam menunjukkan tidak ada pengaruh pemahaman agama terhadap perilaku seksual berisiko. Hasil penelitian ini tidak sejalan dengan penelitian yang dilakukan oleh Dasril menunjukkan ada hubungan yang sangat signifikan antara religiusitas dengan sikap terhadap perilaku pacaran pada santri Pondok Pesantren Ahlul Quran Palembang menunjukkan nilai koefisien korelasi $r=0,602$ dengan nilai signifikansi $(p)=0,000$ atau dengan kata lain $p<0,01$, bahwa ada hubungan yang sangat signifikan antara religiusitas dengan sikap terhadap pacaran pada santri Pondok Pesantren Ahlul Quran Palembang. ${ }^{13}$

Adanya hubungan yang bermakna antara pemahaman siswa SMAN 6 dengan perilaku seksual berisiko menunjukkan adanya pemahaman agama yang baik. Temuan ini didukung oleh Handayani menunjukkan bahwa pengetahuan agama berhubungan dengan perilaku seksual pada remaja. Pengetahuan agama yang baik pada remaja didukung oleh pendidikan agama yang cukup dari keluarga, sekolah dan lingkungan masyarakat. ${ }^{14}$ Hasil penelitian lain oleh Hull, et. al. menunjukkan kategori pemuda religius sangat percaya bahwa melakukan hubungan intim akan membuat orang tua mereka marah. Menghadiri ibadah keagamaan sesekali mungkin memberi manfaat dalam hal menahan diri untuk tidak melakukan perilaku seksual. ${ }^{15}$

Dalam kehidupan modern sekarang ini, remaja sangat perlu meningkatkan keimanan dan ketaqwaan sesuai dengan agama yang dianutnya, karena pemahaman agama yang dimiliki remaja juga dapat memengaruhi mereka dalam berperilaku. Agama secara luas dilihat sebagai pelindung terhadap masalah perilaku remaja pada umumnya dan remaja pengambilan risiko seksual khususnya. Hubungan negatif antara religiusitas 
dan aktivitas seksual remaja cukup kuat dan menjadi dasar kesimpulan bahwa religiusitas bersifat protektif. Tempat spiritual dan pelayanan keagamaan sebagai faktor yang sangat penting untuk memengaruhi keputusan siswa tentang perilaku berisiko seksual. ${ }^{11}$

Tahap perkembangan kognitif, remaja dapat menentukan tindakannya sendiri, namun penentuan diri remaja dalam berperilaku banyak dipengaruhi oleh tekanan dari kelompok teman sebaya (peer groups). Hal ini karena perkembangan sosial pada masa remaja lebih banyak melibatkan kelompok teman sebaya dari pada orang tua. Kelompok Teman sebaya dijadikan sumber referensi utama bagi remaja dalam hal persepsi dan sikap yang berkaitan dengan gaya hidup. Teman sebaya merupakan salah satu sumber informasi tentang seks yang cukup signifikan dalam membentuk pengetahuan, sikap dan perilaku seksual remaja, namun informasi yang diperoleh dari teman sebaya dapat menimbulkan dampak negatif. Penelitian yang dilakukan oleh Maryatun menunjukkan bahwa remaja yang memperoleh informasi dari teman sebaya berisiko melakukan perilaku seksual pra nikah 19,727 kali dibanding yang tidak memperoleh informasi seksualitas dari teman sebaya. ${ }^{16}$

Kelompok sebaya adalah kelompok sosial yang terdiri dari orang-orang seumuran dan memiliki minat yang sama dan biasanya setara dalam hal pendidikan dan kelas sosial. ${ }^{13}$ Hasil penelitian di SMAN 6 Makassar menunjukkan bahwa ada pengaruh yang signifikan peran teman sebaya terhadap perilaku seksual berisiko. Sedangkan, di MA Darul Arqam tidak sejalan dengan hasil ini, yaitu tidak ada pengaruh peran teman sebaya terhadap perilaku seksual berisiko pada santri, hal ini dikarenakan peraturan pesantren yang ketat menyangkut pergaulan antar santri, disamping itu kegiatan keagamaan di pesantren yang padat membuat para santri fokus pada pelaksanaan kegiatan tersebut. Pentingnya kelompok teman sebaya karena mereka cenderung menyediakan ruang untuk berteman. Mereka juga membantu memberikan dukungan sosial dan emosional serta identitas dan rasa memiliki ke dalam kelompok sosial, terutama selama masa remaja. Peçi menemukan bahwa perilaku seksual adalah salah satu dari banyak tempat dimana remaja dipengaruhi oleh teman dan teman terbaik mereka. Remaja cenderung berhubungan seks jika teman dan teman sebayanya lebih tua, menggunakan alkohol atau narkoba, atau terlibat dalam perilaku negatif lainnya ${ }^{17}$

Hasil penelitian ini didukung oleh $\mathrm{Ku}-$ sumastuti yang menunjukkan adanya pengaruh teman sebaya dan akses informasi secara positif berpengaruh dan signifikan terhadap perilaku seksual pada remaja di SMA Negeri 1 Bergas Semarang, hal ini sejalan dengan hasil di SMA Negeri 6 Makassar. Peran orang tua juga berpengaruh terhadap perilaku seksual remaja di SMAN 1 Bergas. ${ }^{18}$ Penelitian ini juga sejalan dengan penelitian Agustin tentang pengaruh penggunaan akses internet dan perilaku teman sebaya terhadap perilaku seksual remaja disalah satu SMA di Kota Semarang, bahwa hasil temuan tersebut menunjukkan ada pengaruh perilaku teman sebaya terhadap perilaku seksual remaja. Sedangkan akses internet tidak ada pengaruhnya terhadap perilaku seksual remaja. ${ }^{19}$

Media sosial adalah media yang menggunakan teknologi berbasis web untuk menyebarluaskan secara cepat pengetahuan dan informasi kepada pengguna internet. Hasil penelitian menunjukkan bahwa penggunaan media sosial lebih rendah pada santri dibandingkan dengan siswa SMA. Hal ini disebabkan oleh adanya aturan kuat bahwa selama di lingkungan asrama atau pondok pesantren, santri tidak diperbolehkan membawa alat komunikasi seperti handphone, oleh karena handphone menjadi media utama remaja saat ini untuk mengakses layanan situs media sosial apapun. Internet merupakan sumber informasi yang paling sering digunakan serta dinilai remaja paling berpengaruh terhadap perilaku seksual. ${ }^{20}$

Hasil penelititan menunjukkan bahwa media sosial berpengaruh terhadap perilaku sosial berisiko siswa SMAN 6 Makassar, sedangkan tidak ada pengaruh media sosial terhadap perilaku seksual pada santri MA Darul Arqam. Santri pondok pesantren sudah paham bahwa perilaku seksual merupakan salah satu perbuatan yang dilarang dan mendekati zina. Santri sudah mendapatkan pengetahuan tentang agama yang diajarkan oleh pihak pondok pesantren.

Adanya pengaruh sosial media terhadap perilaku seksual remaja di SMAN 6 Makassar menunjukkan media memiliki efek negatif karena dapat diakses secara terbuka di sekolah maupun 
lingkungan luar sekolah. Hasil penelitian ini sejalan dengan yang dilakukan oleh Alfarista bahwa ada hubungan sumber informasi (audio visual, media cetak, internet dan tenaga kesehatan) dengan perilaku seksual berisiko pada remaja. ${ }^{20}$ Penelitian ini didukung oleh penelitian Arulogun et. al. mengenai pengaruh paparan internet terhadap perilaku seksual remaja dalam sebuah distrik perkotaan di Nigeria Barat Daya menunjukkan perubahan perilaku seksual dilaporkan $31,1 \%$ responden setelah terpapar situs seksual eksplisit dan 19,5\% mempraktikkan apa yang telah dilihat. Praktik yang terlibat dalam post-exposure meliputi seks oral $(48,3 \%)$, body tattoo $(18,3 \%)$, memiliki banyak pasangan seksual $(11,6 \%)$ dan homoseksualitas $(5,0 \%)$. Pengguna harian $(95 \% \mathrm{CI} O R=1.168$ 3.497) dan laki-laki $(95 \% \mathrm{CI}$ OR $=-1.245-6.465)$ lebih cenderung mengunjungi situs pornografi dibandingkan dengan responden lainnya. ${ }^{21}$

Madrasah Aliyah Darul Arqam Gombara Makassar tetap mengimbangi trend global berkembang yang dapat meningkatkan mutu pendidikan yaitu memiliki pendidikan berbasis TIK (Tekonologi Infomasi dan Komunikasi). Sekolah memfasilitasi laboratorium komputer yang hanya digunakan saat proses belajar mengajar, tidak dipergunakan diluar dari waktu tersebut. Hal ini dikarenakan para pihak sekolah merasa khawatir jika santrinya akan mudah terpengaruh dampak negatif dari internet terutama pengaruh buruk akan hadirnya berbagai bentuk pornografi terhadap kalangan remaja baik dalam bentuk website, video games dan masih banyak lagi sosial media yang dapat mempengaruhi perilaku seksual pada remaja. Hal ini dijelaskan dalam penelitian Collins, et. al., menunjukkan bahaya sosial media dalam memengaruhi perilaku seksual termasuk permainan video (video games) yang diperkirakan jumlah konten seksual dalam permainan video menunjukkan tingkat tinggi, dengan $27 \%$ sampai $36 \%$ permainan berisi bahasa dan gambar seksual eksplisit dan $46 \%-47 \%$ berisi gambar perempuan yang seksual. Mengingat banyaknya penelitian yang melihat kandungan kekerasan dalam game dan kemungkinan dampaknya, tampaknya tepat dan cukup mudah untuk melakukan pekerjaan analog mengenai konten seksual dalam permainan. ${ }^{22}$

Studi dalam temuan Oladeji dan Ayangunna, juga mampu menetapkan parameter seperti, menghabiskan banyak waktu dengan media, menonton orang dewasa berorientasi video, melihat pesan eksplisit secara seksual secara online, menonton program dengan konten seksual di televisi, mendengarkan lirik seksual telah dibuktikan berkontribusi pada peningkatan perilaku seksual berisiko remaja. ${ }^{23}$ Informasi dan rangsangan seksual melalui media massa yang bersifat pornografi menigkatkan kejadian perilaku seksual remaja dan seseorang yang menjalankan ibadahnya kurang patuh maka kecenderungan melanggar jadi lebih besar. ${ }^{8}$

\section{KESIMPULAN DAN SARAN}

Pengaruh pemahaman agama, peran teman sebaya dan media sosial siswa SMAN 6 Makassar terhadap perilaku seksual remaja menunjukkan siswa mendapatkan pemahaman agama tidak hanya di ruang lingkup sekolah tetapi lebih luas memperoleh pemahaman agama dari luar sekolah seperti orang tua sebagai sumber lain. Hal ini berbeda dengan santri di MA Darul Arqam yang hanya memperoleh pemahaman agama dari ruang lingkup pesantren. Namun, pemahaman agama di pesantren lebih produktif karena berasal dari pengajar yang mendalami ilmu agama. Peran teman sebaya dan media sosial pada siswa cenderung lebih rentang terhadap pengaruh perilaku seksual berisiko dibandingkan dengan santri karena akses sosial media santri lebih terbatas dan pergaulan teman sebaya yang lebih protektif karena tidak ada kontak langsung dengan lawan jenis. Hal ini berbeda dengan siswa SMAN 6, siswa dengan siswi berada dalam ruang lingkup yang sama dalam proses belajar-mengajar dan aktivitas lainnya.

Disarankan agar guru atau pihak asrama hendaklah terus memberikan dan meningkatkan pemahaman pendidikan agama terhadap santri dan sebaiknya diadakan sosialisasi ataupun seminar kaitannya dalam bidang perkembangan informasi. Santri harus segera disadarkan ancaman kemajuan teknologi informasi dan komunikasi kalau tidak diimbangi dengan benteng ilmu agama akan berakibat fatal. Bagi orangtua sebaiknya mengawasi dan memberikan arahan pada anak agar menggunakan media sosial secara bijak dan lebih baik memfasilitasi sarana yang lebih bermanfaat agar dapat digunakan oleh santri tersebut diwaktu luangnya untuk melakukan hal-hal yang lebih positif. 


\section{DAFTAR PUSTAKA}

1. Prasetyo, Dwi Sunar. Knowing Yourself. Yogyakarta: Saufa; 2013.

2. Khaerina, S, S. \& Abrham, J. Sexual Disorders and Right-Wing Authorianism in Indonesia Boarding School. Internasional Journal of Research Studies in Psychology. 2014; 3(4): 99-109.

3. Survei Demografi Kesehatan Indonesia. Kesehatan Reproduksi Remaja. Jakarta: SDKI, BPS dan BKKBN; 2012.

4. BKKBN Provinsi Sulawesi Utara. Menengok Pacaran dan Perilaku Seksual Remaja Melalui Sebuah Survei RPJMN Remaja dari tahun 2012-2014 di Sulawesi Utara. Sulawesi Utara: BKKBN; 2016.

5. Paseno, Matilda Martha. Determinan Perilaku Seksual Pranikah Pada Mahasiswa STIK Stella Maris Makassar [Tesis]. Makassar: Universitas Hasanuddin; 2016.

6. Oluwatoyin, Famutimi Esther, \& Modupe O, Oyetunde. Risky Sexual Behaviour among Secondary School Adolescents in Ibadan North Local Government Area, Nigeria. IOSR Journal of Nursing and Health Science (IOSR-JNHS). 2014; 3(4): 34-44.

7. Handebo, Simegnew, Kebede, Yohannes \& Morankar, Sudhakar N. Does Social Connectedness Influence Risky Sexual Behaviours? Finding From Ethiopian Youths. International Journal of Adolescence and Youth. 2017;7: 1-14.

8. Sarwono, Sarlito W. Psikologi Remaja: Edisi Revisi. Jakarta: Rajawali Pers; 2011.

9. Gustina, Erni. Komunikasi Orangtua-Remaja Dan Pendidikan Orangtua Dengan Perilaku Seksual Berisiko Pada Remaja. Unnes Journal of Public Health. 2017;6(2): 131-136.

10. Landor, A., et. al. The Role of Religiosity in the Relationship Between Parents, Peers, and Adolescent Risky Sexual Behavior. Journal of Youth and Adolescence. 2011;40(3):296-309.

11. Abebe, M, Tsion A, \& Netsanet, F. Living With Parents and Risky Sexual Behaviors among Preparatory School Students in Jimma Zone, South West Ethiopia. African Health Sciences. 2013;13(2): 498-506.

12. Wahyu, Purwaningsih \& Maryatun. Hubu- ngan Pengetahuan dan Peran Keluarga dengan Perilaku Seksual Pra Nikah Pada Remaja Anak Jalanan di Kota Surakarta. Jurnal Ilmu Kesehatan Gaster. 2012;9(2): 22-29.

13. Dasril. Hubungan Antara Religiusitas dengan Sikap Terhadap Pacaran pada Santri Pondok Pesantren Ahlul Quran Palembang [Skripsi]. Palembang: Universitas Bina Darma Palembang; 2014.

14. Handayani, Sri. Pengetahuan Agama Berhubungan dengan Perilaku Seksual pada Remaja di SMAN 1 Soppeng Riaja Kabupaten Barru. Jurnal Kesehatan Masyarakat. 2016; 1(4): 1-5.

15. Hull, S. J. et. al. Identifying the Causal Pathways from Religiosity to Delayed Adolescent Sexual Behavior. Journal of Sex Research. 2011;48(6):543-553.

16. Maryatun. Peran Teman Sebaya Terhadap Perilaku Seksual Pra Nikah Pada Remaja di SMA Muhammadiyah 3 Surakarta. Jurnal Ilmu Kesehatan Gaster. 2013;10(2): 39-47.

17. Peçi, Blerta. Peer Influence and Adolescent Sexual Behavior Trajectories: Links to Sexual Initation. European Journal of Multidiscip- 1inary Studies. 2017;4(1-4):96-105.

18. Kusumastuti, Sartika. Pengaruh Faktor Personal dan Lingkungan Terhadap Perilaku Seksual Pada Remaja [Tesis]. Surakarta: Universitas Sebelas Maret; 2015.

19. Agustin, Esti. Pengaruh Penggunaan Akses Internet dan Perilaku Teman Sebaya terhadap Perilaku Seksual Remaja Tahun 2011 (Studi Kasus pada Siswa Kelas XI di Salah Satu SMA di Kota Semarang [Skripsi]. Semarang: Universitas Negeri Semarang; 2012.

20. Alfarista, Dina Aprillia, dkk. Hubungan Sumber Informasi dengan Perilaku Seksual Berisiko Remaja di Kecamatan Sumbersari Kabupaten Jember [Skripsi]. Jember: Universitas Jember; 2013.

21. Arulogun, Oyedunni S, Ibadan, Isaac \& Dipeolu, Oluwafemi. Influence ff Internet Exposure on Sexual Behaviour of Young Persons in an Urban District of Southwest Nigeria. Pan African Medical Journal. 2016;(7):1-8.

22. Collins, Rebecca L., Martino, Steven C. \& Shawrand, Rebecca. Influence of New Media on Adolescent Sexual Health: Evidence and 
Opportunities Report. Washington, D.C.: Office of The Assistant Secretary for Plannning and Evaluation: U.S. Department of Health \& Human Service; 2011.
23. Oladeji, D \& Ayangunna, JA. Media Influence as Predictors of Adolescent's Sexual Risky Behaviour in Nigeria. MedCrave Online Journal of Women's Health (MOJWH). 2017;5(1):1-6. 